\title{
The effects of environmental tax on Ecological Footprint and Carbon dioxide emissions: a nonlinear cointegration analysis on Turkey
}

\author{
Osman Murat Telatar ${ }^{1}$ (D) Nagihan Birinci $^{2}$ (D)
}

Received: 5 December 2021 / Accepted: 14 January 2022 / Published online: 7 February 2022

(c) The Author(s), under exclusive licence to Springer-Verlag GmbH Germany, part of Springer Nature 2022

\begin{abstract}
This article presents a nonlinear analysis in Turkey on the effect of an environmental tax (ET) on the ecological footprint (EFP) and carbon dioxide $\left(\mathrm{CO}_{2}\right)$ emissions. In the literature, most of the studies examining the effects of environmental taxes (ETs) on environmental degradation (ED) have used linear methods. The number of studies examining this relationship with nonlinear methods is few. However, there is no study examining the long-run effects of ETs on the EFP, which is one of the most important indicators of ED, using nonlinear analysis. This study contributes to the literature by investigating the longrun effects of ETs on EFP and $\mathrm{CO}_{2}$ emissions in Turkey by nonlinear analysis. Therefore, the model consisting of annual data for the period 1994-2019 was estimated by Dufrénot et al. (2006) nonlinear cointegration test. According to the estimation results obtained, ETs do not have any long-run effects on EFP and $\mathrm{CO}_{2}$ emissions. Accordingly, it can be concluded that ETs in Turkey do not affect preventing ED.
\end{abstract}

Keywords Environmental degradation $\cdot$ Environmental tax $\cdot$ Ecological footprint $\cdot$ Carbon dioxide emission $\cdot$ Nonlinear unit root $\cdot$ Nonlinear cointegration

\section{Introduction}

Individuals and countries can not perform their economic activities without using energy to maintain economic growth and development (Vera and Sauma 2015). Especially in the twentieth century, with the rapid growth of industrialization, intense population growth, and technological developments, the need for energy has increased significantly. This increasing need for energy has resulted in excessive use of natural resources and has increased the demand for fossil fuels such as oil, coal, and natural gas worldwide.

Responsible Editor: Nicholas Apergis

Osman Murat Telatar

omtelatar@ktu.edu.tr

Nagihan Birinci

nbirinci@ktu.edu.tr

1 Department of Economics, Faculty of Economics and Administrative Sciences, Karadeniz Technical University, Trabzon, Turkey

2 Department of Public Finance, Faculty of Economics and Administrative Sciences, Karadeniz Technical University, Trabzon, Turkey
The primary causes of environmental degradation (ED), climate change, and global warming are greenhouse gas emissions from the use of non-renewable energy sources (Babatunde et al. 2017; Lin and Jia 2018). One of the most powerful greenhouse gas emissions is $\mathrm{CO}_{2}$. However, at the global level, reducing carbon emissions, promoting a lowcarbon economy, and implementing low-carbon economic activities are critical for achieving sustainable development. Therefore, ED, climate change, and global warming have become some of the most discussed topics among scientists, politicians, and business circles (Lin and Jia 2018).

In the "Global Weather 2019" report published by the American Institute of Health Effects, it was reported that air pollution ranked 5th among all health risk factors in the world. Furthermore, the intergovernmental panel on climate change advised that global warming be limited to $1.5^{\circ} \mathrm{C}$, or the planet will experience catastrophic climate change by 2030. If unchecked, air pollution and climate change will increase the likelihood of severe widespread and irreversible risks to humans and ecosystems. Therefore, the need to reduce carbon emissions is urgent ( $\mathrm{Li}$ and Peng 2020). In reality, if no meaningful emission reduction is achieved, the global atmosphere temperature may increase between 2.5 and $7.8^{\circ} \mathrm{C}$ by the end of the century. More countries 
are joining in the cooperation agreement on climate change to reduce this great threat facing the world and accelerate the global transition to green and low-carbon sustainable development (Liu 2019).

ED has become one of the greatest threats facing humanity, affecting not just human health but also economic growth (World Bank 2016). According to the United Nations, "if immediate action is not taken, the devastating impact of climate change will be greater than the present COVID-19 pandemic." In essence, the world is far from the target of limiting the global temperature increase to $1.5^{\circ} \mathrm{C}$ specified in the Paris Agreement (UN 2020). Because of energy consumption to boost economic growth it increases atmospheric $\mathrm{CO}_{2}$ emissions, which cause climate change and global warming (Wolde-Rufael and Mulat-Weldemeske 2021).

Sustainable environmental quality is an essential part of successful sustainable economic development. Many studies have suggested that lower carbon emissions improve environmental quality. The expansion in economic activities contributes to environmental problems such as climate change and ED, as it contributes to a significant increase in greenhouse gas emissions, especially carbon emissions (Bashir et al. 2020). Carbon emission remains the main factor among greenhouse gases today, and the rise in emissions is due to the harmful use of non-renewable energies (Ghazouani et al. 2020). Because of intense industrial and economic activities, global energy consumption increased by $2.3 \%$ in 2018 , resulting in a $1.7 \%$ increase in carbon emissions, from 32.5 to 33.1 gigatons. This increase poses a threat to environmental initiatives at the global level, and countries are committed to reducing their carbon emissions to preserve environmental quality (Bashir et al. 2020).

Although carbon emission was primarily used to test the environmental Kuznets curve hypothesis, it does not appear that the carbon emission alone can capture all environmental damage, as it is a pollutant indicator (Saleem et al. 2019). Therefore, while carbon emissions are generally acknowledged as the primary cause of environmental pollution, other indicators also affect environmental pollution. For example, the reduction of biodiversity, the destruction of forests and fertile agricultural lands, and the pollution of natural water resources. Thus, there is a need for a more comprehensive indicator than carbon emissions to represent environmental pollution (Aydın 2020: 138). This indicator is known as ecological footprint (EFP).

Consequently, to measure the total human pressure on the natural environment, the concept of "environmental" or "ecological" footprint is used as a general term for different footprint concepts developed in the last two decades (Hoekstra and Weidmann 2014). The first study on this concept was conducted by Rees (1992). Wackernagel (1994), thus, implemented the concept and the calculation methods related to it. Wackernagel and Rees explained the relationship between EFP and sustainable development in the book they published in 1996 and detailed their EFP calculation methods (Wackernagel and Rees 1996). Recently, the ratio between the existing resources and the global consumption of these resources is now expressed with the concept of EFP. The EFP reveals how many natural resources are consumed by an individual, city, region, state, or by people around the world to meet their needs and wants, which includes the following: food consumption, shelter, transportation, and waste generated and allows to compare specific activities and their effects on the environment and natural resources (Belčáková et al. 2017).

However, compared to carbon emissions, EFP is a more comprehensive measure in terms of detecting ED because it covers the environment in all its dimensions, including multifaceted environmental indicators like built-up lands, carbon emissions, croplands, fishing grounds, grazing lands, and forest areas. Indeed, one of the most important sustainability indicators in today's world is the EFP, together with the green economy (Zahra et al. 2021). The EFP is an effective tool to measure the impact of human consumption on nature and the resources needed to meet human needs (Sun et al. 2020; Zahra et al. 2021). However, economic globalization has strengthened the ties between countries and has caused the EFP of each country to change by exporting the pressure on the environment from the consumer country to the exporting country that supplies goods and services to this country (Sun et al. 2020).

Nevertheless, environmental problems increase the pressure on governments to reduce environmental damage without hindering economic growth (OECD 2011). Because studies on the environment show the net effect of global warming and the need for a global intervention to reduce greenhouse gases. Therefore, governments must implement strong environmental policies that limit the growing dependence on fossil fuels such as oil, natural gas, and coal to reduce the increase in greenhouse gas emissions (Gemechu et al. 2012). Hence, governments have a range of tools such as regulations, information programs, environmental subsidies, and ETs. Among these tools, especially ETs have special significance (OECD 2011) and are included in tax legislation by many countries.

ETs are the most effective policy tool for reducing greenhouse gas emissions (Bashir et al. 2020). It aims to tax carbon emissions to increase energy efficiency, reduce environmental problems, and contribute to the protection of the environment, by internalizing negative externalities in the form of environmental pollution (Shahzad 2020; Kou et al. 2021; Bashir et al. 2021). In particular, it is potentially applied to goods that harm scarce natural resources (Rafique et al. 2021). ETs directly address market failure that causes markets to ignore environmental impacts. A well-designed ET raises the price of a good or activity to reflect the cost 
of environmental damage to others (OECD 2011). Accordingly, ETs refer to taxes applied to internalize environmental externalities. Because activities that cause greenhouse gas emissions, or more environmental pollution, are relatively not expensive. Individuals or firms do not consider the costs that emissions impose on others, especially future generations. A tax to be applied will force the units that cause the externality to consider all the consequences of this externality (Metcalf and Weisbach 2013). Simultaneously, they are based on the Pigouvian tax, which is levied to burden the companies that emit external damage with the cost of the harm they cause to the society and are based on the polluter pays principle (Kou et al. 2021). According to the polluter pays principle, economic actors can strengthen pollution regulation or adopt cleaner production techniques. They can also reduce pollution emissions to internalize the external cost of pollution by analyzing cost-effectiveness (Lai et al. 2020). In addition, these taxes can contribute to the improvement of environmental quality by motivating the manufacturing sector to develop efficient technologies or producing environmentally friendly products (Jeager 2013; Elkins and Barker 2001; Rafique et al. 2021).

The European Union's (EU) official statistics evaluate ET revenues under four main groups, allowing for international comparisons. These are energy taxes, transport taxes, pollution taxes, and natural resource taxes (Eurostat 2013). From these taxes, energy taxes are collected on energy products such as coal, petroleum products, natural gas, and electricity used for both fixed and transportation purposes. Transport taxes mainly include taxes on the ownership and use of motor vehicles. Pollution and natural resource taxes, on the other hand, cover different tax types, whereas natural resource taxes are collected as the rental price of oil and mines (Eurostat 2021). Energy taxes are levied to reduce carbon emissions. The general purpose of transportation taxes is to contribute to the measures aimed at reducing carbon emissions and protecting the environment. Natural resource taxes, however, are levied to reduce environmental wastes originating from mines.

ETs in Turkey are not applied to solve environmental problems. In reality, the only tax put into practice to prevent environmental pollution and activities that will cause pollution is the environmental cleaning tax (ECT). However, taxes such as special consumption tax (SCT) and motor vehicle tax (MVT) applied in Turkey have possible effects on the environment. Hence, they can be considered as an ET. Consequently, some existing taxes in Turkey that fall under the categories specified in the EU classification have an environmental character in terms of their effects. The share of ET revenues in total tax revenues is an indicator of the importance that countries attach to ETs. In terms of the share of ETs in total tax revenues, Turkey ranks high among OECD countries. However, the reason for this situation is not because of the importance Turkey gives to ETs. The primary reason is due to the structure of the Turkish Tax System (TTS).

This study investigates the long-run effects of ETs on EFP and $\mathrm{CO}_{2}$ emissions in Turkey by performing nonlinear time series analysis and thus contributing to the literature. In the second part of the study, information about the environmental tax system in Turkey is given. The literature section, which includes studies investigating the relationship between ETs and ED, is included in the third part of the study. The data set, model, and methodology are presented in the fourth section and the estimation results are evaluated in the fifth section. The final section contains the conclusions and policy recommendations.

\section{Environmental taxes in Turkey}

There are differences between environmental taxes (ETs) in Turkey and ETs in the EU and OECD countries in terms of the purpose and method of application, and the application area of these taxes in Turkey remains at a very limited level. In fact, the first and only tax put into effect for environmental purposes in the TTS is ECT. In addition, the application of charging for plastic bags, which is a fairly new application and has been implemented as of 2019, also aims to combat environmental pollution. Apart from these, there is no tax applied directly for environmental purposes in the TTS. However, MVT and SCT also indirectly contribute to the prevention of environmental pollution in terms of rates, tariffs, exemptions, and exceptions (Ertekin and Dam 2020).

When evaluated in general, ETs in the TTS do not have the desired environmental impact. However, taxes that can be described as ETs in Turkey seem to have an important share when considering total tax revenues. Namely, Turkey is one of the five OECD countries with the highest share of ETs in total tax revenues with $9.6 \%$ in 2019. Again for the same year, the share of ETs in GDP in Turkey is $2.2 \%$, which is above the OECD average of 1.5\% (OECD 2021a, 2021b).

The main ET in the TTS is the ECT. According to the Law on Municipal Revenues No. 2464 in Turkey, buildings located within the municipal boundaries and adjacent areas and benefiting from the environmental cleaning services of the municipalities are subject to ECT. The amount of this tax is calculated on the basis of the amount of water consumption and is collected by the municipalities (Official Gazette 2021, and numbered 31,696). Calculation of the ECT based on the amount of water consumption and not including other solid wastes shows that this tax is applied independently of the pollution given to the environment. This situation prevents the establishment of a relationship between tax and pollution. For this reason, it is difficult 
to say that the ECT is an effective tool in the fight against environmental pollution.

Another practice that can be described as an ET in Turkey is to charge plastic bags. Due to the negative environmental effects of disposable plastic shopping bags, many countries have introduced various regulations to reduce their use (Muposhi et al. 2021). Turkey is one of the countries that take measures to reduce the use of plastic bags. In this sense, the regulation regarding the charging for plastic bags, which is also called the plastic bag tax in Turkey, was made with the 13th article added to the Environment Law in 2018. The application was started as of January 1, 2019. The aim is efficient management of resources and prevention of environmental pollution caused by plastic bags. In this context, plastic bags are given to the user or the consumer for a fee at the sale points (Official Gazette 2018, and numbered 30,621). As a result of this practice, there was a $75 \%$ decrease in the use of plastic bags in 2019 and 2020. In addition, 354 thousand tons of plastic waste originating from plastic bags and 14 thousand 640 tons of greenhouse gas emissions were prevented (Republic of Turkey Ministry of Environment, Urbanization and Climate Change 2021).

Although the MVT is not applied as an ET in Turkey, it can indirectly contribute to the environment. MVT, which is referred to as wealth tax in the TTS, is determined according to various vehicle types and characteristics in accordance with Law No. 197. With the regulation that entered into force in 2018, in addition to various issues such as the weight, cylinder volume, and age of the vehicle, the value of the vehicle is also taken into account in calculating the tax amount (Motor Vehicle Tax Law 1963). However, $\mathrm{CO}_{2}$ emissions are not taken into account in determining the tax amount. In the EU, while the MVT is primarily aimed at protecting the environment, in Turkey, more priority is given to financial purposes such as financing the budget deficit (Tunç 2019). Taking the MVT according to the cylinder volume of the vehicle in Turkey can make a positive contribution to the prevention of ED. However, lower taxation of old and second-hand vehicles may lead consumers to use such vehicles, which are more likely to produce high carbon emissions. On the other hand, gasoline consumption is taxed at a higher rate than diesel consumption (OECD 2019). All of the above-mentioned reasons weaken the effectiveness of the motor vehicle tax on preventing ED in Turkey.

Another type of tax that indirectly contributes to the environment in Turkey is the SCT. SCT is an expenditure tax that is collected on a fixed or proportional basis on certain goods or products that are generally to luxury and harmful to health and the environment. This tax has come to the fore with the law changes made within the framework of harmonization with the EU in Turkey (OECD 2006). The purpose of applying this tax in the EU is to provide social benefits rather than income. In Turkey, on the other hand, the effect of the SCT on the prevention of environmental pollution occurs mostly indirectly. For example, reducing consumption by increasing fuel prices can be shown as one of these indirect effects. However, while determining the tariff in taxation, the amount of consumption is taken as a basis, not the emission of the fuel to the environment, and the tax rate may vary according to the fuel type. This situation makes it difficult for the SCT to be a tool to prevent environmental pollution and brings the financial purpose to the fore (Çelikkaya 2011).

\section{Literature}

Whether ETs are effective in preventing ED has become popular with the signing of the Kyoto protocol in the late 1990s and has begun to be studied. At the beginning of the pioneering studies on this subject in the literature, Tamura et al. (1996) is coming. According to the results of the input-output analysis carried out with the data of 1985, they determined that environmental taxes reduced $\mathrm{CO}_{2}$ emissions in Japan. Similarly, Tamura et al. (1999) showed that carbon and energy taxes are effective in reducing $\mathrm{CO}_{2}$ emissions, according to the results of the input-output analysis they performed with the 1990 data for Japan.

An important part of the studies investigating the effects of ET on ED consists of studies based on panel regression analysis. Lin and $\mathrm{Li}$ (2011) examined the effects of carbon taxes on $\mathrm{CO}_{2}$ emissions in Denmark, Finland, the Netherlands, Norway, and Sweden for the 1981-2008 period using panel regression estimation. According to the empirical findings from the study, carbon taxes do not have any effect on $\mathrm{CO}_{2}$ in other countries except Finland. On the other hand, Morley (2012) finds that carbon taxes have reducing effects on greenhouse gas emissions by performing a panel regression estimation on $24 \mathrm{EU}$ countries and Norway for the period 1995-2006. Likewise, Miller and Vela (2013) and Lai et al. (2020) observed that ETs are an effective policy tool in preventing EDs, according to their panel regression analysis results for fifty countries and China, respectively. There are also studies examining the long-run relationship between ET and ED with the panel cointegration method. For example, Sasmaz (2016), who examined the effects of ET on $\mathrm{CO}_{2}$ emissions in EU-15 countries with the 1995-2012 data using panel cointegration test and fully modified ordinary least squares (FMOLS) estimation, found that the variables were cointegrated and ETs had a negative effect on $\mathrm{CO}_{2}$. Bashir et al. (2020) and Rafique et al. (2021) also examined it with the help of the panel cointegration test for 29 OECD countries. According to the results of both studies, it was determined that the variables were cointegrated and that ETs had a reducing effect on $\mathrm{CO}_{2}$ emissions and EFP. Topal (2017), on the other hand, examined the same relationship in 34 
OECD countries for the period 1994-2013 and found that the negative relationship between ET and $\mathrm{CO}_{2}$ emissions was valid only in 20 countries. On the other hand, Tekin and Şaşmaz (2016) stated that ETs do not have any effect on $\mathrm{CO}_{2}$ emissions in EU-25 over the period of 1995-2012.

Some other studies have examined the effects of ETs on ED with the help of general equilibrium model estimation. For example, Meng et al. (2013) determined that carbon taxes are effective in reducing $\mathrm{CO}_{2}$ emissions, according to the results of the general equilibrium model they estimated for Australia with 2011 data. Lin and Jia (2018) and Niu et al. (2018) also examined the relationship between ET and $\mathrm{CO}_{2}$ emissions for China with the help of general equilibrium model estimation. According to the empirical results obtained from both studies, ETs have a reducing effect on $\mathrm{CO}_{2}$ emissions.

In the literature, the number of studies examining the relationship between ET and ED with the help of time series analysis is very few. Among these studies, Sarıgül and Topçu (2021) analyzed the relationship between ET and $\mathrm{CO}_{2}$ emissions in Turkey with annual data for the period of 1994-2015. According to the FMOLS and dynamic ordinary least squares (DOLS) estimation results, ETs which had a reducing effect on $\mathrm{CO}_{2}$ emission was determined. Esen and Dündar (2021) used the same methods for Turkey and found that energy taxes have a reducing effect on $\mathrm{CO}_{2}$ emissions. Akkaya and Hepsag (2021), unlike Sarıgül and Topçu (2021) and Esen and Dündar (2021), examined the subject with nonlinear time series analysis. According to the empirical results obtained from the study, there is no relationship between fuel tax and $\mathrm{CO}_{2}$ emissions in Turkey. Another study based on nonlinear analysis Ulucak et al. (2020) examined the effects of ETs on $\mathrm{CO}_{2}$ emissions in Brazil, China, India, and South Africa by using nonlinear smooth transition regression estimation over the period of 1994-2015. They found that there is a positive relationship between $\mathrm{ET}$ and $\mathrm{CO}_{2}$ emissions in the lower regime of globalization, and a negative relationship between the variables in the higher regime of globalization. Wolde-Rufael and Mulat-Weldemeskel (2021) examined the effects of environmental and energy taxes on $\mathrm{CO}_{2}$ emissions in 9 countries with a panel augmented mean group estimation. According to the linear model estimation results obtained from the empirical analysis, environmental and energy taxes do not have any effect on $\mathrm{CO}_{2}$. On the other hand, the nonlinear model estimation results reveal that both taxes are effective in reducing $\mathrm{CO}_{2}$ emissions. The literature table containing the empirical studies on the subject is presented in Table 1 .

As can be seen in Table 1, $\mathrm{CO}_{2}$ emissions have been used as an indicator of ED in a significant part of the studies in the literature. On the other hand, the number of studies using the EFP, which is a more comprehensive indicator of ED, is very few. However, almost all of the studies on the subject are based on the estimation of linear models. The number of studies conducted with nonlinear estimation methods is rare. Moreover, there is no study examining the effects of ETs on EFP using nonlinear methods. Therefore, in this study, it is aimed to contribute to the literature by investigating the effect of ETs on $\mathrm{CO}_{2}$ emissions and EFP with nonlinear time series analysis.

\section{Data, model, and methodology}

\section{Data description and model specification}

The aim of this study is to reveal the effect of ETs applied in Turkey on ED. In the literature, $\mathrm{CO}_{2}$ emissions are mostly used as an indicator of ED. However, EFP is accepted as a more comprehensive indicator of ED. While $\mathrm{CO}_{2}$ emissions include emissions from energy use and industrial activities, the EFP also includes cropland, fishing grounds, forest area, and built-up and grazing lands. Although the number of studies examining the effects of ETs on $\mathrm{CO}_{2}$ emissions is many, there are limited studies examining the effects on the EFP. Hence, both $\mathrm{CO}_{2}$ emissions and EFP variables were used as indicators of ED in this study. For this purpose, ET was used as an independent variable, and EFP and $\mathrm{CO}_{2}$ emission variables were used as dependent variables. The models estimated in the analysis are as follows.

$\mathrm{EFP}_{\mathrm{t}}=\alpha_{0}+\alpha_{1} \mathrm{ET}_{\mathrm{t}}+\mathrm{u}_{1 \mathrm{t}}$

$\mathrm{CO}_{2 \mathrm{t}}=\beta_{0}+\beta_{1} \mathrm{ET}_{\mathrm{t}}+\mathrm{u}_{2 \mathrm{t}}$

With the help of these models, the long-run effects of the ET variable on the EFP and $\mathrm{CO}_{2}$ emissions were investigated using time series analysis. By using Model (1), the effect of ET on the EFP, and with the help of Model (2), the effect of the ET on $\mathrm{CO}_{2}$ emissions was investigated. The sample range covers the period 1994-2017 for Model (1) and 1994-2019 for Model (2). The reason why the sample period started in 1994 is that the ET variable started in 1994 for Turkey, and why it ended in 2017 and 2019 because the EFP and $\mathrm{CO}_{2}$ emission variables have data until 2017 and 2019 , respectively. The variables used in the above models and the databases from which they were provided are shown in detail in Table 2.

\section{Estimation methods}

The economic theory considers that most time series variables can have a nonlinear structure. For example, the downward rigidity of wages is an important example of this situation. In addition, the fact that the contraction period is generally longer than the expansion period in 
Table 1 Empirical literature on environmental degradation and environmental tax

\begin{tabular}{|c|c|c|c|c|}
\hline Author & Country & Sample & Method & Findings \\
\hline Tamura et al. (1996) & Japan & 1985 & -Input-output analysis & - Carbon tax $\rightarrow \mathrm{CO}_{2}(-)$ \\
\hline Tamura et al. (1999) & Japan & 1990 & -Input-output analysis & $\begin{array}{l}\text { - Carbon tax } \rightarrow \mathrm{CO}_{2}(-) \\
\text { energy tax } \rightarrow \mathrm{CO}_{2}(-)\end{array}$ \\
\hline Lin and Li (2011) & $\begin{array}{l}\text { Denmark, Finland, Netherlands, } \\
\text { Norway, Sweden }\end{array}$ & 1981-2008 & -Panel regression estimation & $\begin{array}{l}\text { - Carbon tax } \rightarrow \mathrm{CO}_{2}(-) \\
\text { /(only for Finland) }\end{array}$ \\
\hline Morley (2012) & 24 EU countries and Norway & 1995-2006 & -Panel regression estimation & $\begin{array}{l}\text { - Carbon tax } \rightarrow \text { greenhouse gas } \\
\text { emission (-) }\end{array}$ \\
\hline Meng et. al (2013) & Australia & 2011 & $\begin{array}{l}\text {-Computable general equilib- } \\
\text { rium (CGE) model estimation }\end{array}$ & $\begin{array}{l}\text { - Carbon tax } \rightarrow \text { carbon emissions } \\
(-)\end{array}$ \\
\hline Miller and Vela (2013) & 50 countries & 1995-2008 & -Panel regression estimation & - $\mathrm{ET} \rightarrow \mathrm{CO}_{2}(-)$ \\
\hline Sasmaz (2016) & EU-15 countries & 1995-2012 & $\begin{array}{l}\text {-Panel cointegration test } \\
\text {-Panel FMOLS }\end{array}$ & $\begin{array}{l}\text { - Cointegrated } \\
\text { - } \mathrm{ET} \rightarrow \mathrm{CO}_{2}(-)\end{array}$ \\
\hline Tekin and Şaşmaz (2016) & EU-25 countries & 1995-2012 & $\begin{array}{l}\text {-Panel cointegration test } \\
\text {-Panel FMOLS } \\
\text {-Panel causality test }\end{array}$ & $\begin{array}{l}\text { - Cointegrated } \\
\text { - } \mathrm{ET} \nrightarrow \mathrm{CO}_{2}(-) \\
\text { - } \mathrm{ET} \leftrightarrow \mathrm{CO}_{2} \text { /causality }\end{array}$ \\
\hline Topal (2017) & 34 OECD countries & 1994-2013 & $\begin{array}{l}\text {-Panel cointegration test } \\
\text {-Panel FMOLS } \\
\text {-Panel causality test }\end{array}$ & $\begin{array}{l}\text { - Cointegrated } \\
\text { - } \mathrm{ET} \rightarrow \mathrm{CO}_{2}(-) /(\text { for } 20 \text { countries) } \\
\text { - } \mathrm{ET} \rightarrow \mathrm{CO}_{2} / \text { causality }\end{array}$ \\
\hline Lin and Jia (2018) & China & 2010 & -CGE model estimation & - Carbon tax $\rightarrow \mathrm{CO}_{2}(-)$ \\
\hline Niu et al. (2018) & China & - & $\begin{array}{l}\text {-Dynamic stochastic general } \\
\text { equilibrium (DSGE) model }\end{array}$ & $\begin{array}{l}\bullet \mathrm{ET} \rightarrow \mathrm{CO}_{2} \\
\text { variance decomposition } \\
\text { impulse-response functions }\end{array}$ \\
\hline Aydın (2020) & 11 OECD countries & 1995-2016 & -Fourier causality test & $\begin{array}{l}\text { - ET } \rightarrow \text { EFP/Germany, Sweden, } \\
\text { Denmark } \\
\text { - EFP } \rightarrow \text { ET/France, Spain } \\
\text { - ET } \leftrightarrow \text { EFP/ Belgium, Neth- } \\
\text { erlands, UK, Italy, Norway, } \\
\text { Portugal }\end{array}$ \\
\hline Bashir et al. (2020) & 29 OECD countries & 1995-2015 & $\begin{array}{l}\text {-Panel cointegration test } \\
\text {-Panel regression estimation } \\
\text {-Panel causality test }\end{array}$ & $\begin{array}{l}\text { - Cointegrated } \\
\text { - } \mathrm{ET} \rightarrow \mathrm{CO}_{2}(-) \\
\text { /regression } \\
\text { - ET } \leftrightarrow \mathrm{CO}_{2} \text { /causality }\end{array}$ \\
\hline Sun et al. (2020) & China & 2015 & $\begin{array}{l}\text {-Dynamic CGE model estima- } \\
\text { tion }\end{array}$ & - Energy tax $\rightarrow$ EFP(-) \\
\hline Lai et al. (2020) & China & 2005-2015 & -Panel regression estimation & $\begin{array}{l}\text { - Resource tax } \rightarrow \text { pollution(-) } \\
\text { - Excise tax } \nrightarrow \text { pollution }\end{array}$ \\
\hline Ulucak et al. (2020) & $\begin{array}{l}\text { Brazil, China, India, South } \\
\text { Africa }\end{array}$ & 1994-2015 & $\begin{array}{l}\text {-Nonlinear panel regression } \\
\text { estimation } \\
\text { (smooth transition regression) }\end{array}$ & $\begin{array}{l}-\mathrm{ET} \rightarrow \mathrm{CO}_{2}(+) \\
/ \text { lower regime of globalization } \\
\bullet \mathrm{ET} \rightarrow \mathrm{CO}_{2}(-) \\
\text { /higher regime of globalization }\end{array}$ \\
\hline Akkaya and Hepsag (2021) & Turkey & $1985-2018$ & $\begin{array}{l}\text {-Nonlinear cointegration test } \\
\text {-Nonlinear causality test }\end{array}$ & $\begin{array}{l}\text { - No cointegration } \\
\text { - Fuel tax } \nrightarrow \mathrm{CO}_{2} \\
\text { /causality }\end{array}$ \\
\hline Esen and Dündar (2021) & Turkey & 1994-2017 & $\begin{array}{l}\text {-Johansen cointegration test } \\
\text {-FMOLS } \\
\text {-DOLS }\end{array}$ & $\begin{array}{l}\text { - Cointegrated } \\
\text { - Energy tax } \rightarrow \text { carbon emission } \\
(-) \\
\text { /FMOLS, DOLS }\end{array}$ \\
\hline Rafique et al. (2021) & $\begin{array}{l}29 \text { OECD } \\
\text { countries }\end{array}$ & 1994-2016 & $\begin{array}{l}\text {-Panel cointegration test } \\
\text {-Panel autoregressive dis- } \\
\text { tributed lag (ARDL) model } \\
\text { estimation } \\
\text {-Panel causality test }\end{array}$ & $\begin{array}{l}- \text { Cointegrated } \\
-\mathrm{ET} \rightarrow \mathrm{EFP}(-) / \text { long and short } \\
\text { run } \\
\text { - } \mathrm{ET} \leftrightarrow \mathrm{EFP} / \text { causality }\end{array}$ \\
\hline Sarıgül and Topçu (2021) & Turkey & 1994-2015 & $\begin{array}{l}\text {-Johansen cointegration test } \\
\text {-FMOLS } \\
\text {-DOLS }\end{array}$ & $\begin{array}{l}\text { - Cointegrated } \\
\text { - ET } \rightarrow \mathrm{CO}_{2}(-) \\
/ \text { FMOLS, DOLS }\end{array}$ \\
\hline
\end{tabular}


Table 1 (continued)

\begin{tabular}{|c|c|c|c|c|}
\hline Author & Country & Sample & Method & Findings \\
\hline $\begin{array}{l}\text { Wolde-Rufael and Mulat- } \\
\text { Weldemeskel (2021) }\end{array}$ & $\begin{array}{l}9 \text { countries } \\
\text { (Czech Republic, Greece, } \\
\text { Hungary, Korea, Poland, South } \\
\text { Africa, and Turkey) }\end{array}$ & 1994-2015 & $\begin{array}{l}\text {-Panel augmented mean group } \\
\text { (AMG) estimation } \\
\text {-Panel Granger causality test }\end{array}$ & $\begin{array}{l}\text { - For linear model } \\
\mathrm{ET} \leftrightarrow \mathrm{CO}_{2} \\
\text { energy tax } \rightarrow \mathrm{CO}_{2}(-) \\
\text { - For nonlinear model } \\
\mathrm{ET} \rightarrow \mathrm{CO}_{2}(-) \\
\text { energy tax } \rightarrow \mathrm{CO}_{2}(-) \\
\text { - ET } \leftrightarrow \mathrm{CO}_{2} / \mathrm{causality} \\
\text { energy tax } \leftrightarrow \mathrm{CO}_{2} / \text { causality }\end{array}$ \\
\hline
\end{tabular}

Table 2 Variables used in the analysis and databases

\begin{tabular}{lll}
\hline Variable & Definition & Database \\
\hline ET & $\begin{array}{l}\text { Environmental tax } \\
\text { (as a percentage of GDP) }\end{array}$ & OECD \\
EFP & $\begin{array}{l}\text { Ecological footprint } \\
\text { (gha per person) }\end{array}$ & $\begin{array}{c}\text { Global } \\
\text { Footprint }\end{array}$ \\
& $\begin{array}{l}\text { Notal carbon dioxide emissions } \\
\mathrm{CO}_{2}\end{array}$ & OECD \\
& $\begin{array}{l}\text { (Tonnes of } \mathrm{CO}_{2} \text { equivalent, thou- } \\
\text { sands, in logarithmic form) }\end{array}$ & \\
\hline
\end{tabular}

cyclical fluctuations indicates that basic macroeconomic variables such as production and employment decrease more difficult than their increases. Since standard ARMA (autoregressive moving average) models are based on linear difference equations, new dynamic specifications are needed to reveal the nonlinear structure (Enders 2010). For this reason, the research of nonlinearity in economics has been increasing in recent years. Similarly, there is growing suspicion that the findings from linear time series analysis may be insufficient to draw conclusions about macroeconomic issues. Especially, the findings obtained from Dickey-Fuller (DF) unit root and Engle and Granger (1987) cointegration tests have been very effective in the emergence of these doubts. Therefore, researchers tend toward nonlinear dynamics in estimation and inference (Kapetanios et al., 2003a, 2006).

The existence of nonlinear structure has also led to the emergence of regime-switching models. These models differ from each other according to the size (intensity, shape) of the transition between regimes. If the transition between regimes occurs abruptly, the threshold is autoregressive (TAR), if it is slow (smooth), there is a smooth transition autoregressive (STAR) model. In addition, artificial neural networks and Markov switching model are other regime switching models in the literature. Although there are many alternative methods for modeling nonlinearity, STAR modeling is one of the most common methods used. It is more appropriate to use STAR models to describe data especially during asymmetric cycle variations and economic fluctuations (Skalin and Teräsvirta 1999).
The number of studies on this subject in the literature is high and most of the studies are based on linear model estimation. Similarly, linear model analysis was used for studies conducted in Turkey. As mentioned in detail above, macroeconomic variables can follow nonlinear processes due to different reasons such as data generation processes, changing sub-items, or changing base years (Telatar 2016). For this reason, in the empirical part of this study, firstly, whether the variables follow a nonlinear process will first be determined. For this purpose, a nonlinear unit root test will be applied to each of the variables. If at least one of the variables in the model follows a nonlinear process, the existence of cointegration between the variables will be investigated using the nonlinear method.

\section{Nonlinear unit root analysis}

In a significant number of studies in the literature, unit root tests are conducted based on the linear approach. Although linear unit root tests are widely used, the criticisms of these tests are increasing. For example, Phillips (1987) and Kwiatkowski et al. (1992) in small samples, Geweke and PorterHudak (1983) and Robinson (1994) in the case of fractional cointegration, Bierens (1997) and Kapetanios et al. (2003b) in the presence of nonlinear structure argue that the augmented Dickey-Fuller (ADF) unit root test does not yield effective results. In addition, since an incorrect specification in deterministic components may affect the validity of the relevant test, criticisms are increasing against the classical unit root hypotheses that do not consider the possibility of nonlinearity in deterministic components (Liu and He 2010).

Alternative approaches have been developed to determine whether the variables contain a unit root or not, after the increase in criticism toward linear unit root tests. Studies in this direction in the literature are conducted in two different ways. The first is to use the panel data set to increase the power of standard unit root tests, while the other is the use of fractional cointegration or nonlinear forms of time series models. Studies such as Balke and Fomby (1997), Enders and Granger (1998), Berben and van Dijk (1999), Caner and Hansen (2001), Lo and Zivot (2001), and Kapetanios and Shin (2006) examined the relationship between cointegration 
and nonlinearity by examining the interactions; they discussed the unit root analysis within the framework of the nonlinear model. (Kapetanios et al. 2003b).

Similarly, Kapetanios, et al. (2003b) developed a new approach that considers the nonlinear structure in unit root testing, unlike classical unit root tests. According to this test, which is called the KSS test (Kapetanios, Shin and Shell) in the literature, the null hypothesis asserts that there is the unit root, while the alternative hypothesis expresses a nonlinear exponential smooth transition autoregressive (ESTAR) model process, unlike ADF (Bahmani-Oskooee and Gelan 2006). The model to be estimated and the hypotheses to be tested in the KSS test are obtained as a result of the following process (Kapetanios et al. 2003b):

First, a univariate first-order STAR model can be written as follows.

$y_{t}=\beta y_{t-1}+\gamma y_{t-1} \Theta\left(\theta ; y_{t-d}\right)+\varepsilon_{t}, \mathrm{t}=1, \ldots, \mathrm{T}$

In Eq. (3), $\Theta\left(\theta ; y_{t-d}\right)$ is the transition function, $\theta$ is the transition parameter of the STAR process, which determines the transition rate, $\beta$ and $\gamma$ are the unknown parameters, and $\varepsilon_{t}$ is the homoskedastic normal distributed error term. If the transition function is written in the exponential form of the STAR model, it becomes as follows.

$\Theta\left(\theta ; y_{t-d}\right)=1-\exp \left(-\theta y_{t-d}^{2}\right)$

The above equation assumes $\theta \geq 0$ and delay parameter $d \geq 1$. Therefore, the exponential transition function lies between 0 and 1 .

$\Theta(0)=0 ; \lim _{x \rightarrow \pm \infty} \Theta(x)=1$

Exponential STAR (ESTAR) model is obtained by using Eqs. (3) and (4).

$y_{t}=\beta y_{t-1}+\gamma y_{t-1}\left[1-\exp \left(-\theta y_{t-d}^{2}\right)\right]+\varepsilon_{t}$

The above equation can be represented as follows when it is reparameterised.

$\Delta y_{t}=\varnothing y_{t-1}+\gamma y_{t-1}\left[1-\exp \left(-\theta y_{t-d}^{2}\right)\right]+\varepsilon_{t}$

where $\theta=\beta-1$. Assuming $\theta=0$ is positive allows the speed of mean revision to be effectively defined. If $\varnothing$ is accepted as zero, it means that $y_{t}$ follows the unit root process in the middle regime. The null hypothesis $\left(\mathrm{H}_{0}\right)$ expresses the linear unit root process with the assumptions $\varnothing=0$ and $\theta=0$. In other words, the series contains a unit root and has a linear structure. The alternative hypothesis $\left(\mathrm{H}_{1}\right)$, on the other hand, states that $y_{t}$ follows a nonlinear but stationary process with the assumptions $\varnothing=0$ and $\theta>0$.

When $\varnothing=0$ and $d=1$ are accepted, Eq. (6) will be rewritten as follows:
$\Delta y_{t}=\gamma y_{t-1}\left\{1-\exp \left(-\theta y_{t-1}^{2}\right)\right\}+\varepsilon_{t}$

KSS testing is directly based on the $\theta$ parameter. Therefore, the null and alternative hypotheses to be tested are as follows.

$\mathrm{H}_{0}: \theta=0$.

$\mathrm{H}_{1}: \theta>0$.

Since the $\gamma$ parameter is not defined under the $\mathrm{H}_{0}$, it will not be appropriate to directly test the $\mathrm{H}_{0}$. For this reason, the following auxiliary regression equation is obtained by applying the first-order Taylor series approximation.

$\Delta y_{t}=\delta y_{t-1}^{3}+\varepsilon_{t}$

The extended version of the above auxiliary regression can be written as Eq. (9).

$\Delta y_{t}=\delta y_{t-1}^{3}+\sum_{k=1}^{n} \rho_{k} \Delta y_{t-1}+\varepsilon_{t}$

In the above equation, $y_{\mathrm{t}}$ is the variable analyzed for the unit root and $n$ is the optimal lag length that has no autocorrelation problem. The null and alternative hypotheses belonging to Eq. (9) are as follows:

$\mathrm{H}_{0}: \delta=0$.

$\mathrm{H}_{1}: \delta>0$.

The $t$-statistic $\left(t_{\mathrm{NL}}\right)$, which will be obtained from the $\delta$ parameter because of the estimation of Eq. (9), allows testing the null and alternative hypotheses. The $t_{\mathrm{NL}}$ statistic is calculated according to the following equation:

$t_{N L}=\widehat{\delta} / s . e(\widehat{\delta})$

In the above equation, $\hat{\delta}$ is the ordinary least squares (OLS) estimation result of $\delta$, and s.e. represents the standard error. The $t_{\mathrm{NL}}$ statistic compares with the critical table values prepared by Kapetanios et al. (2003b) since it does not have an asymptotic normal distribution. Accordingly, if the calculated $t_{\mathrm{NL}}$ statistic is less than the critical table value, the null hypothesis cannot be rejected. Here, it is decided that the relevant series contains a unit root and has a linear process. If the calculated $t_{\mathrm{NL}}$ statistic is greater than the critical table value, the null hypothesis is rejected. Thus, it is decided that the series is stationary but follows a nonlinear process.

\section{Nonlinear cointegration test}

Along with the increase in studies on nonlinear analyses in the literature, the number of studies examining the cointegration relationship with the nonlinear method has started to increase. Kapetanios et al. (2003a) developed a new test method for the detection of the cointegration relationship following the stationary STAR process. According to this new test they have developed, the cointegration relationship 
can be determined in two different ways. The first one is to determine the cointegration with the nonlinear error correction mechanism. The second is achieved by obtaining the nonlinear version of the linear Engle and Granger (1987) approach based on residuals. Similarly, Dufrénot et al. (2006) cointegration test refer to the nonlinear form of Engle and Granger (1987) cointegration test. Engle and Granger (1987) cointegration test consists of two stages. In the first stage, the model in which the long-run relationship is investigated is estimated by the OLS method. In the second stage, the residues obtained from the OLS estimation are subjected to unit root testing. Dufrénot et al. (2006) performed the nonlinear version of the Engle and Granger (1987) test by performing a nonlinear unit root test on the residues in this second stage (Telatar 2013). The theoretical background of Dufrénot et al. (2006) nonlinear cointegration test can be expressed with the help of the following process.

Let $z_{\mathrm{t}}$ be the residues obtained from the first step of the cointegration test. For simplicity, assuming $z_{\mathrm{t}}$ follows a 1 delay STAR process, the nonlinear cointegration test is performed as follows (Dufrénot et al. 2006):

$z_{t}=\rho_{1} z_{t-1}+\rho_{1}^{*} z_{t-1} F\left(x_{t-d}, \theta\right)+v_{t}$

In Eq. (11), $v_{t}$ is the error term, $x_{t-d}$ is the transition variable representing the regime transition dynamic in the correction process, and $F($.) represents the logistic or exponential function type of the STAR model.

$F\left(x_{t-d}\right)=\left\{1+\exp \left[-\gamma\left(x_{t-d}-c\right)\right]\right\}^{-1}, \gamma>0 \theta=(\gamma, c)$

$F\left(x_{t-d}\right)=1-\exp \left[-\gamma\left(x_{t-d}-c\right)^{2}\right], \gamma>0 \theta=(\gamma, c)$

In the above equations, $\gamma$ represents the transition parameter controlling the size of the transition between regimes and the threshold value $c$. Here, the transition variables are $z_{t-d}$ or $\Delta z_{t-d}$. Of these, $z_{t-d}$ indicates the effect of the current deviation on the future deviation, while $\Delta z_{t-d}$ indicates the variability feature of the deviation in the long-run equilibrium. Assuming $\rho=1$ and $-2<\rho_{1}^{*}<0$, Eq. (11) will be rewritten as follows:

$\Delta z_{t}=\left[\tilde{\rho}_{1}+\rho_{1}^{*} F\left(x_{t-d}, \theta\right)\right] z_{t-1}+v_{t}, \tilde{\rho}_{1}=\rho_{1}-1$

The hypotheses to be tested in Eq. (14) are as follows:

$\mathrm{H}_{0}: \tilde{\rho}_{1}=\rho_{1}^{*}=0$ (randomwalk)

$\mathrm{H}_{1}: \tilde{\rho}_{1}=0,-2<\rho_{1}^{*}<0$ (nonlinearmean - reversion)

Since the parameters of the STAR models are not defined in the null hypothesis above, a form of $\Delta z_{t}$ including logistic and exponential functions is created. Thus, the following auxiliary regression is obtained in the logistic function model.

$\Delta z_{t}=\phi_{0}^{1} z_{t-1}+\phi_{1}^{1} z_{t-1} x_{t-d}+\phi_{3}^{1} z_{t-1} x_{t-d}^{3}+\omega_{t}^{1}$

In the above equation, $z_{t}$ is residuals from the first stage of the cointegration test, $x_{t}$ is the independent variable. $z_{t-1} x_{t-d}$ indicates the interaction term and the subscript $d$ represents the optimum lag length with a minimum AIC value that does not contain autocorrelation problems. The null hypothesis to investigate the existence of cointegration is as follows:

$\mathrm{H}_{0}: \phi_{1}^{1}=\phi_{3}^{1}=0$

The two statistics, named STAT1 and STAT2, are used to test the null hypothesis.

$S T A T 1=\frac{T\left(S S R_{0}-S S R_{1}\right)}{S S R_{0}}$

$S T A T 2=\left[\frac{\left(S S R_{0}-S S R_{1}\right)}{S S R_{0}}\right]\left[\frac{n d_{1}}{\left(n d_{0}-n d_{1}\right)}\right]$

In Eqs. (16) and (17), $T$ is the number of observations, the sum of the squared residuals for the null hypothesis is $S S R_{0}$, and the sum of the squared residuals for the alternative hypothesis is $S S R_{l}$. Lastly, the number of degrees of freedom under the $\mathrm{H}_{\mathrm{o}}$ and $\mathrm{H}_{1}$ respectively are $n d_{0}$ and $n d_{l}$. The STAT1 and STAT2 statistics obtained with the help of the above equations are compared with the table values created according to the Monte Carlo simulations, and a decision is made about the null hypothesis. Besides, the test of the null hypothesis, in other words, the existence of nonlinear cointegration can also be performed by determining whether the $z_{\mathrm{t}}$ series contains a unit root. For this purpose, whether the $\phi_{0}^{1}$ coefficient in Eq. (15) is statistically significant is tested. If that coefficient is statistically insignificant, the null hypothesis cannot be rejected and no cointegration between the variables is decided. Otherwise, the null hypothesis is rejected, meaning that nonlinear cointegration can exist.

\section{Empirical results}

As mentioned in the estimation method part of the study, estimating the model, which includes a variable with a nonlinear structure, by linear methods will lead to questioning the conformity and consistency of the results obtained. For this reason, in the empirical part of the study first, whether the variables followed a nonlinear process was determined. For this purpose, the KSS unit root test was applied to the variables based on the probability that the series used in 
Table 3 The results of nonlinear unit root test

\begin{tabular}{lllll}
\hline Variable & $t_{\mathrm{NL}}$ & \multicolumn{3}{l}{ Probability level values } \\
\cline { 3 - 5 } & & 0.01 & 0.05 & 0.10 \\
\hline $\mathrm{ET}$ & $-2.998(0)^{\mathrm{a}}$ & -2.82 & -2.22 & -1.92 \\
& $-2.452(0)^{\mathrm{b}}$ & & & \\
$\mathrm{EFP}$ & $-0.552(0)$ & & & \\
$\mathrm{CO}_{2}$ & $-1.562(0)$ & & & \\
\hline
\end{tabular}

The values in parentheses indicate the optimum lag length determined according to AIC. Probability level values were obtained from Kapetanios et al., (2003b) Table $1 .^{\mathrm{a}}$ and ${ }^{\mathrm{b}}$ show the $t_{\mathrm{NL}}$ statistics for the sample period included in model (1) and model (2), respectively

the study could follow a nonlinear stationary process. The results of this nonlinear unit root test are given in Table 3.

As shown in Table 3, the null hypothesis was not rejected because the test statistics of the EFP and $\mathrm{CO}_{2}$ series were smaller than the table critical values. Therefore, both series follow a linear process. In other words, EFP and $\mathrm{CO}_{2}$ variables, which are used as indicators of environmental degradation in the study, have a linear structure. However, the null hypothesis was rejected because the test statistic of the ET series was greater than the table critical values. Therefore, by accepting the alternative hypothesis, the ET series does not contain a unit root and has a nonlinear structure can be said. According to the KSS test findings, while the EFP and $\mathrm{CO}_{2}$ series contain unit roots and follow a linear process [I(1)], the ET series are stationary and follow a nonlinear $[\mathrm{I}(0)]$ process. These results suggest that the ET series for Turkey has a nonlinear structure and therefore shocks to ETs may affect environmental variables such as EFP and $\mathrm{CO}_{2}$ in a nonlinear way. For this reason, an empirical model including ETs should be estimated by nonlinear methods. As a result, especially since the ET series has a nonlinear process, analyzing the model in which ET takes place with linear methods may cause false estimation results. Thus, the existence of cointegration between the variables was investigated with the help of a nonlinear cointegration test.

Since the ET series, which is the independent variable of both models examined in the study, has a non-stationary structure, cointegration models in which long-run relationships are investigated should also be estimated by nonlinear methods. For this reason, the existence of a long-run relationship between the variables in the study was examined with the help of Dufrénot et al. (2006) nonlinear cointegration test. The Dufrénot et al. (2006) cointegration test is performed by applying a unit root to the residuals in the cointegration model, as in the Engle and Granger cointegration test. Applied in this study, Dufrénot et al. (2006) nonlinear cointegration test results are shown in Table 4.

As can be seen in Table 4, the coefficient of the error term lag in the model in which the cointegration between ET and
Table 4 The results of Dufrénot et al. (2006) cointegration test

\begin{tabular}{lllll}
\hline Model & $d$ & $\phi_{0}^{1 *}$ & Prob & Decision \\
\hline $\mathrm{EFP}=\mathrm{f}(\mathrm{ET})$ & 1 & -3.758 & 0.144 & $\begin{array}{l}\mathrm{H}_{0} \text { cannot be rejected } \\
\text { (not cointegrated) }\end{array}$ \\
$\mathrm{CO}_{2}=\mathrm{f}(\mathrm{ET})$ & 1 & -0.890 & 0.251 & $\begin{array}{l}\mathrm{H}_{0} \text { cannot be rejected } \\
\text { (not cointegrated) }\end{array}$ \\
\hline
\end{tabular}

$*$ is the coefficient of error term lag in Eq. (15) and $d$ indicates the optimum lag length in the interaction term

EFP was investigated is -3.758 . However, the null hypothesis cannot be rejected as this coefficient is statistically insignificant. Therefore, the variables are not cointegrated which means that the ET and EFP variables do not move together in the long run. In other words, there is no long-run relationship from ET to EFP. Similarly, the coefficient of the error term lag in the model in which the cointegration between ET and $\mathrm{CO}_{2}$ was investigated is -0.890 . In this model, as in the previous model, the coefficient of the error term lag is statistically insignificant, too. Accordingly, the error term series in the nonlinear cointegration equation is not stationary. Therefore, the null hypothesis claiming that there is no cointegration between the variables cannot be rejected. In other words, the ET and $\mathrm{CO}_{2}$ variables do not move together in the long run.

Finally, as shown in Table 4, in both models where ET is the independent EFP and $\mathrm{CO}_{2}$ are the dependent variables, the coefficients of the error term lag are statistically insignificant and the null hypothesis, which indicates that the variables are not cointegrated, cannot be rejected. These results reveal that the variables for both models are not cointegrated. Accordingly, ETs in Turkey do not have any effect on EFP and $\mathrm{CO}_{2}$ in the long run.

\section{Concluding remarks}

With the acceleration of industrialization, dense population growth, and technological developments, the need for energy, which is an indispensable element of human life, has also increased. Increasing energy demand has led to excessive use of natural resources and has increased the demand for fossil fuels such as oil, natural gas, and coal worldwide. Because of the increase in the use of fossil fuels, which are harmful to the environment, the number of greenhouse gases emitted to the atmosphere, especially $\mathrm{CO}_{2}$, has increased. $\mathrm{CO}_{2}$ emissions are accepted as the main cause of environmental pollution. However, other factors are affecting environmental pollution, such as the reduction of biological diversity, the destruction of forests and fertile agricultural areas, and the pollution of natural water resources. For this reason, a more comprehensive indicator than $\mathrm{CO}_{2}$ emissions is needed to fully express and draw the framework of 
environmental pollution. This indicator is described as the EFP and it is argued that the EFP variable better represents environmental pollution compared to $\mathrm{CO}_{2}$ emissions.

Therefore, environmental pollution is one of the negative externalities that prevents the efficient distribution of scarce resources and the realization of economic activities. One of the main objectives of the global world order is to be able to combat environmental pollution at a global level and to improve the quality of the environment, thus protecting the environment and reducing the factors that cause damage to the environment. ETs are at the forefront of the financial instruments that will serve this purpose. Environmental taxes in Turkey do not find application areas in the same sense as in EU or OECD countries. The main tax applied for environmental purposes in Turkey is ECT. In addition, it is possible to evaluate the practice of charging for plastic bags, implemented in Turkey as of 2019, within the scope of ETs. Apart from these two applications, there is no ET implemented for environmental purposes in TTS. However, MVT, which is among the wealth taxes in Turkey, and SCT, which is one of the expenditure taxes, can make a positive contribution to the environment due to their possible effects on the environment. However, these effects are quite limited. As a matter of fact, these taxes are not applied due to environmental concerns. The main purpose is rather to generate income. On the other hand, the share of ETs in total tax revenues is important in terms of the importance given to ETs. Turkey is one of the OECD countries with the highest share of ETs in total tax revenues. However, this is not due to the importance given to ETs, but to the structure of the tax system.

This study investigates the long-run effects of ETs on the EFP and $\mathrm{CO}_{2}$ emissions from the 1994-2019 period in Turkey by using nonlinear time series analysis. Due to the unit root analysis, it was determined that the ET variable followed a nonlinear process. However, due to the cointegration test applied, it was determined that the variables were not cointegrated. In other words, ETs do not have any long-run effects on the EFP and $\mathrm{CO}_{2}$ emissions in Turkey. Therefore, the ET policy implemented in Turkey has no contribution to preventing or reducing ED. ETs in Turkey are not effective in preventing ED since they are allocated to increase public revenues rather than environmental purposes. This result also reveals that the ET policy that Turkey has followed is not effective. Thus, the "Law on Approval of the Paris Agreement" by the Turkish Grand National Assembly entered into force by being published in the Official Gazette on October 7, 2021, and numbered 31,621. According to Turkey's national contribution statement, it is foreseen that greenhouse gas emissions will be reduced by $21 \%$ in 2030 compared to the reference scenario. Therefore, Turkey's reevaluation of its ET policy, if made more effective, will contribute significantly to achieving its greenhouse gas emission reduction target. For this reason, instead of expecting an indirect effect from taxes such as wealth tax and expenditure tax, the implementation of a direct environmental tax such as carbon tax may play a more effective role in preventing environmental degradation.

Author contribution OMT: analyzed and interpreted the literature and performed the empirical models. NB: determined the subject of study and interpreted introduction and ETs in Turkey sections. All authors have contributed to the conclusion remarks section and read and approved the final manuscript.

Data availability The datasets generated and/or analyzed during the current study are available in the [Organisation for Economic Co-operation and Development, Global Footprint Network] repository [https:// data.oecd.org/https://www.footprintnetwork.org/].

\section{Declarations}

Ethics approval and consent to participate Not applicable.

Consent for publication Not applicable.

Competing interests The authors declare no competing interests.

\section{References}

Akkaya Ş, Hepsag A (2021) Does fuel tax decrease carbon dioxide emissions in Turkey? evidence from an asymmetric nonlinear cointegration test and error correction model. Environ Sci Pollut Res 28:35094-35101. https://doi.org/10.1007/ s11356-021-12907-9

Aydın M (2020) Seçilmiş OECD ülkelerinde çevre vergilerinin çevre kirliliği üzerine etkileri: yapısal kırılmalı nedensellik testinden kanitlar. Uluslararası İktisadi ve İdari İncelemeler Dergisi 28:137154. https://doi.org/10.18092/ulikidince.704936

Babatunde KA, Begum RA, Said FF (2017) Application of computable general equilibrium (CGE) to climate change mitigation policy: a systematic review. Renew Sustain Energy Rev 78:61-71. https:// doi.org/10.1016/j.rser.2017.04.064

Bahmani-Oskooee M, Gelan A (2006) Testing the PPP in the nonlinear STAR framework: evidence from Africa. Economics Bulletin 6(17): $1-15$

Balke NS, Fomby TB (1997) Threshold cointegration. Int Econ Rev 38:627-645. https://doi.org/10.2307/2527284

Bashir MF, MA B, Shahbaz M, Jiao Z (2020) The nexus between environmental tax and carbon emissions with the roles of environmental technology and financial development. Plos One 15(11):1-20. https://doi.org/10.1371/journal.pone.0242412

Bashir MF, MA B, Komal B, Bashir MA (2021) Analysis of environmental taxes publications: a bibliometric and systematic literature review. Environ Sci Pollut Res 28:20700-20716. https://doi.org/ 10.1007/s11356-020-12123-x

Belčáková I, Diviaková A, Belaňová E (2017) Ecological footprint in relation to climate change strategy in cities. IOP Conf. Series: Materials Science and Engineering 245. https://doi.org/10.1088/ 1757-899X/245/6/062021

Berben R, van Dijk D (1999) Unit root tests and asymmetric adjustment: a reassessment. Unpublished manuscript. Tinbergen Institute, Erasmus University of Rotterdam 
Bierens HJ (1997) Testing the unit root with drift hypothesis against nonlinear trend stationarity, with an application to the U.S. price level and interest rate. J Econ 81:29-64. https://doi.org/10.1016/ S0304-4076(97)00033-X

Caner M, Hansen BE (2001) Threshold autoregression with a near unit root. Econometrica 69:1555-1596. https://www.jstor.org/stable/ 2692267. Accessed 10 July 2021

Çelikkaya A (2011) Avrupa Birliği üyesi ülkelerde çevre vergisi reformları ve Türkiye'deki durumun değerlendirilmesi. Anadolu Üniversitesi Sosyal Bilimler Dergisi 11(2):97-120

Dufrénot G, Mathieu L, Mignon V, Péguin-Feissolle A (2006) Persistent misalignments of the European exchange rates: some evidence from nonlinear cointegration. Appl Econ 38:203-229. https://doi.org/10.1080/00036840500390262

Elkins P, Barker T (2001) Carbon taxes and carbon emissions trading. Journal of Economic Surveys 15(3):325-376

Enders W (2010) Applied econometrics time series, 3rd edn. John Wiley \& Sons, Inc, Hoboken

Enders W, Granger CWJ (1998) Unit root tests and asymmetric adjustment with an example using the term structure of interest rates. J Business and Econ Stat 16:304-311. https://doi.org/10.2307/ 1392506

Engle RF, Granger CWJ (1987) Co-integration and error correction: representation, estimation, and testing. Econometrica 55(2):251276. https://doi.org/10.2307/1913236

Ertekin Ş, Dam MM (2020) An evaluation on the environmental impact of environmental taxes in Turkey. Journal of Yasar University, Special Issue on $3^{\text {rd }}$ International EUREFE Congress, pp 66-87

Esen Ö, Dündar M (2021) Do energy taxes reduce the carbon footprint? evidence from Turkey. J Emerg Econ Policy 6(2):179-186

Eurostat (2013) Environmental taxes: A statistical guide. https://ec. europa.eu/eurostat/documents/3859598/5936129/KS-GQ-13-005EN.PDF.pdf/706eda9f-93a8-44ab-900c-ba8c2557ddb0?t=14147 82946000. Accessed 15 May 2021

Eurostat (2021) Environmental tax statistics-detailed analysis. https:// ec.europa.eu/eurostat/statistics-explained/index.php?title=Envir onmental_tax_statistics_-_detailed_analysis. Accessed 23 July 2021

Gemechu ED, Butnar I, Llop M, Castells F (2012) Environmental tax on products and services based on their carbon footprint: a case study for the pulp and paper sector. Elsevier Energy Policy 50:336-344. https://doi.org/10.1016/j.enpol.2012.07.028

Geweke J, Porter-Hudak S (1983) The estimation and application of long memory time series models. J Time Ser Anal 4:221-238. https://doi.org/10.1111/j.1467-9892.1983.tb00371.x

Ghazouani A, Xia W, Jebli MB Shahzad U (2020) Exploring the role of carbon taxation policies on $\mathrm{CO}_{2}$ emissions: contextual evidence from tax implementation and non-implementation European countries. Sustainability. https://doi.org/10.3390/su12208680

Global Footprint Network (2021) Ecological footprint vs biocapacity. https://data.footprintnetwork.org/?_ga=2.48164071.1548574759. $16345755101323550536.1634575510 \# /$ countryTrends? $\mathrm{cn}=223 \&$ type $=$ BCpc,EFCpc. Accessed 10 May 2021

Hoekstra AY, Wiedmann TO (2014) Humanity's unsustainable environmental footprint. Science 344(6188):1114-1117. https://doi. org/10.1126/science. 1248365

Jaeger WK (2013) Double dividend. Encyclopedia of Energy, Natural Resource, and Environmental Economics 1:37-40. https://doi.org/ 10.1016/B978-0-12-375067-9.00073-5

Kapetanios G, Shin Y (2006) Unit root tests in three-regime SETAR models. Economet J 9(2):252-278. https://doi.org/10.1111/j.1368423X.2006.00184.X

Kapetanios G, Shin Y, Snell A (2003a) Testing for cointegration in nonlinear STAR error correction models. University of London Queen Mary Economics Working Paper 497:1-24. https://doi.org/ $10.2139 / \mathrm{ssrn} .428602$
Kapetanios G, Shin Y, Snell A (2003b) Testing for a unit root in the nonlinear STAR framework. Journal of Econometrics 112:359379. https://doi.org/10.1016/S0304-4076(02)00202-6

Kapetanios G, Shin Y, Snell A (2006) Testing for cointegration in nonlinear STAR error correction models. Economet Theor 22:279303. https://doi.org/10.1017/S0266466606060129

Kou P, Han Y, Li Y (2021) An evolutionary analysis of corruption in the process of collecting environmental tax in China. Environ Sci Pollut Res 28:54852-54862. https://doi.org/10.1007/ s11356-021-13104-4

Kwiatkowski D, Phillips PCB, Schmidt P, Shin Y (1992) Testing the null hypothesis of stationarity against the alternative of a unit root. Journal of Econometrics 54:159-178

Lai X, Liu Z, Luo S (2020) Assessment on the effectiveness of environmental regulation in China-evidence from a panel data analysis. Environ Sci Pollut Res 27:37363-37376. https://doi.org/10.1007/ s11356-020-08583-w

Li H, Peng W (2020) Carbon tax, subsidy, and emission reduction: analysis based on DSGE model. Hindawi. Complexity. https:// doi.org/10.1155/2020/6683482

Lin B, Jia Z (2018) The energy, environmental and economic impacts of carbon tax rate and taxation industry: a CGE based study in China. Energy 159:558-568. https://doi.org/10.1016/j.energy. 2018.06.167

Lin B, Li X (2011) The effect of carbon tax on per capita $\mathrm{CO}_{2}$ emissions. Energy Policy 39:5137-5146. https://doi.org/10.1016/j. enpol.2011.05.050

Liu C, He LY (2010) KSS unit root test of nonlinearity an nonstationarity in China's agricultural future markets. Phys Procedia 3:1753-1756. https://doi.org/10.1016/j.phpro.2010.07.015

Liu M (2019) The impact of environmental taxon low-carbon transition. International Journal of Business and Social Science 10(1):95-105. https://doi.org/10.30845/ijbss.v10n1p12

Lo MC, Zivot E (2001) Threshold cointegration and nonlinear adjustment to the law of one price. Macroeconomic Dynamics 5:533576. https://doi.org/10.1017/S1365100500000456

Meng S, Siriwardana M, McNeill J (2013) The environmental and economic impact of the carbon tax in Australia. Environ Resource Econ 54:313-332. https://doi.org/10.1007/s10640-012-9600-4

Metcalf GE, Weisbach D (2013) Carbon taxes. Encyclopedia of Energy, Natural Resource and Environmental Economics 1:9-14. https:// doi.org/10.1016/B978-0-12-375067-9.00126-1

Miller SJ, Vela MA (2013) Are environmentally related taxes effective? Inter-American Development Bank Working Paper Series No. IDB-WP-467:1-23

Morley B (2012) Empirical evidence on the effectiveness of environmental taxes. Appl Econ Lett 19:1817-1820. https://doi.org/10. 1080/13504851.2011.650324

Motor Vehicle Tax Law (1963) https://www.mevzuat.gov.tr/Mevzu atMetin/1.5.197.pdf. Accessed 24 December 2021

Muposhi A, Mpinganjira M, Wait M (2021) Efficacy of plastic shopping bag tax as a governance tool: lessons for South Africa from Irish and Danish success stories. Acta Commercii 21(1):16841999. https://doi.org/10.4102/ac.v21i1.891

Niu T, Yao X, Shao S, Li D, Wang W (2018) Environmental tax shocks and carbon emissions: an estimated DSGE model. Struct Chang Econ Dyn 47:9-17. https://doi.org/10.1016/j.strueco.2018.06.005

Offical Gazzette (2018) https://www.resmigazete.gov.tr/eskiler/2018/ 12/20181210-4.htm. Accessed 24 December 2021

Offical Gazzette (2021) https://www.resmigazete.gov.tr/eskiler/2021/ 12/20211221-10.htm. Accessed 24 December 2021

OECD (2006) Tax policy reforms in Turkey. https://www.oecd.org/tax/ tax-policy/37154710.pdf. Accessed 24 December 2021

OECD (2011) Environmental taxation: a guide for policy makers. https://www.oecd.org/env/toolsevaluation/48164926.pdf. Accessed 14 September 2021 
OECD (2019) OECD environmental performance reviews: Turkey 2019. https://read.oecd-ilibrary.org/environment/oecd-environmen tal-performance-reviews-turkey-2019_9789264309753-en\#page1. Accessed 24 December 2021

OECD (2021a) Environmental tax. https://data.oecd.org/envpolicy/ environmental-tax.htm. Accessed 10 May 2021a

OECD (2021b) Greenhouse gas emissions. https://stats.oecd.org/Index. aspx?DataSetCode=AIR_GHG. Accessed 10 May 2021b

Phillips PCB (1987) Time series regression with a unit root. Econometrica 55(2):277-301. https://doi.org/10.2307/1913237

Rafique MZ, Fareed Z, Ferraz D, Ikram M (2021) Exploring the heterogenous impacts of environmental taxes on environmental footprints: an empirical assessment from developed economies. Energy 238. https://doi.org/10.1016/j.energy.2021.121753

Rees WE (1992) Ecological footprints and appropriated carrying capacity: what urban economics leaves out. Environ Urban 4(2):121-130. https://doi.org/10.1177/095624789200400212

Republic of Turkey Ministry of Environment, Urbanization and Climate Change (2021) https://www.csb.gov.tr/plastik-poset-kulla nimi-yuzde-75-oraninda-azaldi-bakanlik-faaliyetleri-31995. Accessed 24 December 2021

Robinson PM (1994) Efficient tests of nonstationary hypotheses. J Am Stat Assoc 89(428):1420-1437. https://doi.org/10.2307/2291004

Saleem N, Shujah-ur R, Jun Z (2019) The impact of human capital and biocapacity on environment: environmental quality measure through ecological footprint and greenhouse gases. Journal of Pollution Effects \& Control. https://doi.org/10.35248/2375-4397. 19.7.237

Sarıgül SS, Topçu AB (2021) The impact of environmental taxes on carbon dioxide emissions in Turkey. International Journal of Business \& Economic Studies 3(1):43-54

Sasmaz MU (2016). Validity of double dividend hypothesis in EU-15 countries. Global Journal on Humanites \& Social Sciences [Online] 04:30-36. http://sproc.org/ojs/index.php/pntsbs. Accessed 14 September 2021

Shahzad U (2020) Environmental taxes, energy consumption, and environmental quality: theoretical survey with policy implications. Environ Sci Pollut Res 27:24848-24862. https://doi.org/10.1007/ s11356-020-08349-4

Skalin J, Teräsvirta T (1999) Another look at swedish business cycles, 1861-1988. J Appl Economet 14:359-378

Sun Y, Mao X, Liu G, Yin X, Zhao Y (2020) Modelling the effects of energy taxes on ecological footprints transfers in China's foreign trade. Ecological Modelling. https://doi.org/10.1016/j.ecolmodel. 2020.109200

Tamura H, Nakanishi R, Hatono I, Umano M (1996) Is environmental tax effective for total emission control of carbon dioxide? systems analysis of an environmental-economic model. IFAC Proceedings Volumes 29(1):5435-5440. https://doi.org/10.1016/S14746670(17)58546-8

Tamura H, Hotehama M, Tomiyarna S, Hatono I (1999) On environmental tax for total emission control of carbon dioxide. IFAC Proceedings Volumes 32(2):5782-5787. https://doi.org/10.1016/ S1474-6670(17)56987-6
Tekin A, Şaşmaz MÜ (2016) Küreselleşme sürecinde ekolojik riskleri azaltmada çevresel vergilerin etkisi Avrupa Birliği örneği. Yönetim ve Ekonomi 23(1):1-17. https://doi.org/10.18657/yecbu. 20984

Telatar OM (2013) Türkiye'de ikiz açiklar hipotezinin geçerliliği. Yayınlanmamış Doktora Tezi, Karadeniz Teknik Üniversitesi Sosyal Bilimler Enstitüsü

Telatar OM (2016) The effects of foreign portfolio investments on Turkish economic growth: a nonlinear approach. 18th International Scientific Conference on Economic and Social Development-Building Resilient Society. Zagreb, Croatia. December 9-10: 616-622

Topal MH (2017) Çifte kazanç hipotezinin OECD ekonomileri için testi: panel eşbütünleşme ve nedensellik analizi. The Journal of International Scientific Researches 2(4):1-20. https://doi.org/10. 23834/isrjournal.284627

Tunç Z (2019) Motor vhicles tax: some problems and evaluations. 34. International Public Finance Conference. Antalya, Turkey. 24-27:71-76. https://doi.org/10.26650/PB/SS10.2019.001.011

UN (2020) The sustainability development goals report 2020. https:// unstats.un.org/sdgs/report/2020/. Accessed 27 September 2021

Ulucak R, Danish K, Kassouri Y (2020) An assessment of the environmental sustainability corridor: investigating the non-linear effects of environmental taxation on $\mathrm{CO}_{2}$ emissions. Sustain Dev 28:1010-1018. https://doi.org/10.1002/sd.2057

Vera S, Sauma E (2015) Does a carbon tax make sense in countries with still a high potential for energy efficiency? comparison between the reducing-emissions effects of carbon tax and energy efficiency measures in the Chilean case. Energy 88:478-488. https://doi.org/10.1016/j.energy.2015.05.067

Wackernagel M (1994) Ecological footprint and appropriated carrying capacity: a tool for planning toward sustainability. Dissertation, University of British Columbia

Wackernagel M, Rees WE (1996) Our ecological footprint: reducing human impact in the earth. New Society Publishers. https://doi. org/10.5070/G31710273

Wolde-Rufael Y, Mulat-Weldemeskel E (2021) Do environmental taxes and environmental stringency policies reduce $\mathrm{CO}_{2}$ emissions? evidence from 7 emerging economies. Environ Sci Pollut Res 28:22392-22408. https://doi.org/10.1007/s11356-020-11475-8

World Bank (2016) The cost of air pollution-strengthening the economic case for action. The World Bank and Institute for Health Metrics and Evaluation. University of Washington, Seattle. https:// openknowledge.worldbank.org/bitstream/handle/10986/25013/ 108141.pdf?sequence $=4 \&$ isAllowed $=y$. Accessed 27 September 2021

Zahra S, Khan D, Nouman M (2021) Fiscal policy and environment: a long-run multivariate empirical analysis of ecological footprint in Pakistan. Environ Sci Pollut Res. https://doi.org/10.1007/ s11356-021-15665-w

Publisher's note Springer Nature remains neutral with regard to jurisdictional claims in published maps and institutional affiliations. 